\title{
Review on the Wire Arc Additive Manufacturing Process and Trends in Non-ferrous Alloys
}

\author{
Jae-Deuk Kim*,**, Joo Yong Cheon*, and Changwook Ji*, \\ *Advanced Forming Process R\&D Group, Korea Institute of Industrial Technology, Ulsan, 44413, Korea \\ **Department of Materials Science and Engineering, Pusan National University, Busan, 46241, Korea \\ †Corresponding author: cwji@kitech.re.kr \\ (Received November 17, 2021; Revised November 29, 2021; Accepted December 2, 2021)
}

\begin{abstract}
Owing to global trends, automation with the fourth industrial revolution, and environmentally friendly policies owing to certified emission reduction, wire arc additive manufacturing (WAAM) is attracting attention in various industrial fields. In addition, the demands of non-ferrous metals such as aluminum and magnesium alloys are attracting attention from industries that require lightweight, large, and complex metallic parts that can be fabricated through WAAM. In this study, additive manufacturing (AM), WAAM, and current issues on the WAAM of non-ferrous metals particularly aluminum and magnesium alloys are discussed.
\end{abstract}

Key Words: Metal additive manufacturing, Direct energy deposition, Wire arc additive manufacturing, Nonferrous alloys, Aluminum alloy, Magnesiu alloy

\section{Metal additive manufacturing}

Additive manufacturing (AM) has been defined by ASTM as "a process of joining materials to make objects from 3D model data, usually layer upon layer, as opposed to subtractive manufacturing methodologies" $"$. Also, it describes AM "is the general term for those technologies that based on a geometrical representation creates physical objects by successive addition of material. These technologies are presently used for various applications in engineering industry as well as other areas of society, such as medicine, education, architecture, cartography, toys and entertainment" ${ }^{\prime 1)}$. In particular, a metal AM is studied broadly and the metal AM industry is emerging as a new part fabrication method in the past two to three decades ${ }^{2,3}$. When it compared with the conventional manufacturing methods, the metal AM has the numerous advantages such as: i) possible to fabricating complex components, ii) higher energy efficiency, iii) saving materials, iv) shorten manufacturing time and cycle, and etc ${ }^{4}$.

A basic metal AM system is composed of a motion system (robot or gantry), a heat (or energy) source, and a feeding system of the target material ${ }^{5)}$. It is able to use laser beam, electron beam, or arc as the heat source. And the target material can be fed in the form of powder, wire, or sheet ${ }^{4}$. Thus, there is more than hundreds of combinations of different metal AM system at present, and hence, it is obvious that the metal AM is a transformable or flexible process.

There are several categorizing ways of metal AM processes by the terms of heat source, material, or feedstock $^{2,6)}$. The most common way is classifying in two categories depending on the feedstock. One is called powder bed fusion (PBF) process "in which thermal energy selectively fuses regions of a powder bed" and the other is direct energy deposition (DED) "in which focused thermal energy is used to fuse materials by melting as they are being deposited"1). The main difference between PBF and DED is whether the material feeding and melting by the heat source is simultaneous or not. PBF and DED have dozens of branches in each by terms of the type of feeding material and heat source, and some of it shown in Fig. $1^{4,7}$.

DED is the process that material feeding and melting/depositing is simultaneously occurred as mentioned afore. It has comparatively high energy efficiency and 


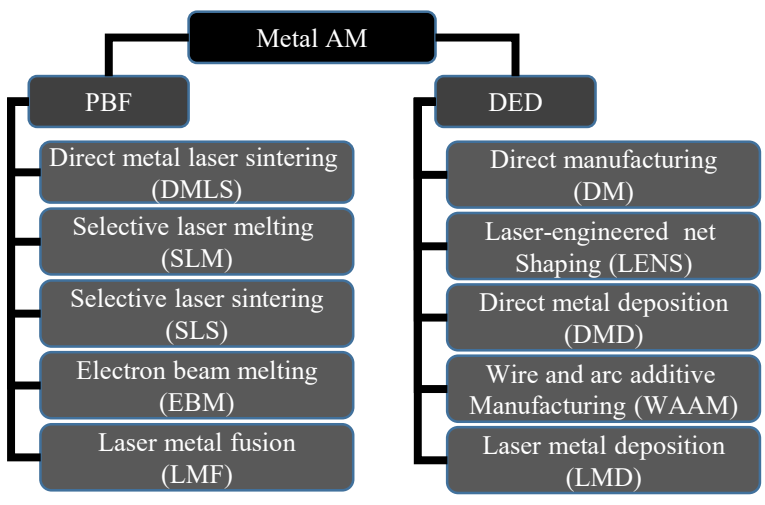

Fig. 1 Summary of representative examples of the metal AM processes ${ }^{7)}$

high deposition rates than $\mathrm{PBF}^{6)}$. DED can save a significant amount of raw material compared with conventional manufacturing methods such as CNC milling with the billet. Also, it does not need any special tool or mold as in casting and forging, hence, it saves material cost, time for tool making, and makes readily modifying the design of the product.

DED can be classified again in terms of the material type it uses; powder or wire. Some of the DED processes using powder and wire are summarized in Table 1 with the heat source, abbreviation, company name, and deposition rates of each process. As seen in Table 1, wire-DED shows two or more times higher deposition rates than powder-DED. This can be advantageous on a fast prototyping or a short delivery time. Further, wire-DED does not need a sealed chamber which is re- quired in PBF and powder-DED processes due to its high reactivity of the melt pool and safety/health issues with the fine metal powders ${ }^{4}$. In other words, wireDED has no limitation in the dimension of the AM product. On the other hand, wire-DED has a lower resolution and rough surface than the PBF and powder-DED due to its high deposition rates and hence it needs additional post-machining processing such as CNC for the accuracy of the product ${ }^{5,89}$. Thus, the wireDED is suitable for fabricating large, medium complexity metallic products ${ }^{6,8,9)}$. Besides, the cost of the metallic powder for powder-DED is much higher than metal wires for wire-DED ${ }^{10)}$. Further, commercial wires for the arc welding are also able to use for wire-DED with various heat sources. It can save the material cost and time for developing materials for DED as it does in $\mathrm{PBF}$ and powder-DED ${ }^{4,10)}$.

\section{Wire arc additive manufacturing}

A wire arc additive manufacturing (WAAM) is the one of wire-DED. WAAM is a process that when the metal wire (feedstock) is melted by the arc (heat source), it transferred into the melt pool and subsequently solidifies and forms a deposited metal along the planned paths layer by layer as shown in Fig. $2^{4,6,8,9,11)}$. WAAM had been invented in 1925 by the Baker, but it had been studied as AM purpose since $1990 \mathrm{~s}^{5,12)}$.

Likewise other AM processes, from a view of the hardware, WAAM also basically consisted with the motion system, heat source, and a feeding system. The

Table 1 Classification of the DED process

\begin{tabular}{|c|c|c|c|c|}
\hline Material type & Power source & Process & Company & Deposition rate \\
\hline \multirow{4}{*}{ Powder } & \multirow{4}{*}{ Laser } & $\begin{array}{c}\text { LENS } \\
\text { (Laser Engineered Net Shaping) }\end{array}$ & Optomec & $0.1 \sim 2 \mathrm{~kg} / \mathrm{h}$ \\
\hline & & $\begin{array}{c}\text { Powder Based Laser DMD } \\
\text { (Direct Metal Deposition) }\end{array}$ & DM3D & $0.1 \sim 2 \mathrm{~kg} / \mathrm{h}$ \\
\hline & & $\begin{array}{c}\text { Powder Based Laser DMT } \\
\text { (Direct Metal Tooling) }\end{array}$ & InssTek & $0.1 \sim 2 \mathrm{~kg} / \mathrm{h}$ \\
\hline & & $\begin{array}{c}\text { Powder Based Laser CLAD } \\
\text { (Construction Laser Additive Direct) }\end{array}$ & BeAM & $0.1 \sim 2 \mathrm{~kg} / \mathrm{h}$ \\
\hline \multirow{7}{*}{ Wire } & Electron beam & $\begin{array}{c}\text { EBAM } \\
\text { (Electron Beam Additive Manufacturing) }\end{array}$ & Sciaky & $\sim 9 \mathrm{~kg} / \mathrm{h}$ \\
\hline & \multirow{2}{*}{$\begin{array}{l}\text { Solid Filler Based } \\
\text { GTAW, GMAW arc }\end{array}$} & \multirow{2}{*}{$\begin{array}{c}\text { WAAM } \\
\text { (Wire Arc Additive Manufacturing) }\end{array}$} & Cranfield Univ. & $\sim 4 \mathrm{~kg} / \mathrm{h}$ \\
\hline & & & KITECH & $\sim 6 \mathrm{~kg} / \mathrm{h}$ \\
\hline & \multirow{2}{*}{$\begin{array}{l}\text { Solid Filler Based } \\
\text { GMAW arc }\end{array}$} & $\begin{array}{c}\text { DML } \\
\text { (Direct Metal Lamination) }\end{array}$ & MUTOH & $\sim 4 \mathrm{~kg} / \mathrm{h}$ \\
\hline & & $\begin{array}{l}\text { Solid Filler Based GMAW arc ADED } \\
\text { (Arc Directed Energy Deposition) }\end{array}$ & EWI & $\sim 4 \mathrm{~kg} / \mathrm{h}$ \\
\hline & \multirow{2}{*}{$\begin{array}{l}\text { Solid Filler Based } \\
\text { Plasma arc }\end{array}$} & $\begin{array}{c}\text { IFF } \\
\text { (Ion Fusion Formation) }\end{array}$ & Honeywell & $\sim 3 \mathrm{~kg} / \mathrm{h}$ \\
\hline & & $\begin{array}{l}\text { Solid Filler Based Plasma arc RPD } \\
\text { (Rapid Plasma Deposition) }\end{array}$ & Norsk titanium & $\sim 6 \mathrm{~kg} / \mathrm{h}$ \\
\hline
\end{tabular}


(a)

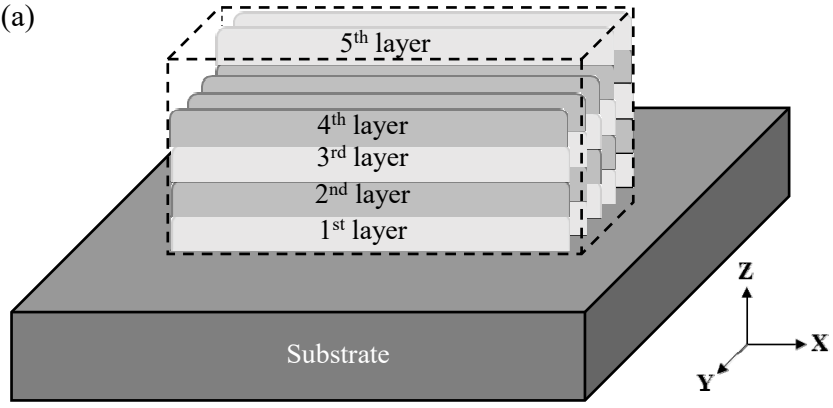

(b)

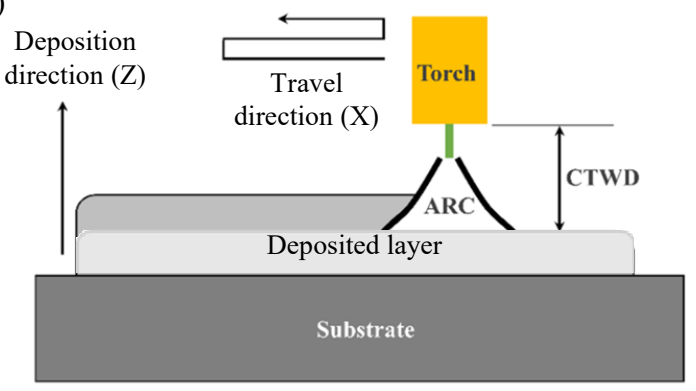

Fig. 2 Schematic diagram of WAAM processes is shown in (a) and Y-axis view of the WAAM process is shown in (b) $)^{8)}$

heat source for the WAAM is generally arc heat sources such as gas tungsten arc welding (GTAW), gas metal arc welding (GMAW), or plasma arc welding (PAW) 2,4,8,9,12). Specific processes are listed and features of each process are described in Table 2. The deposition rate is somewhat varied with the material used as shown in Table 2. Nonetheless, it is common that the deposition rate is highest in tandem GMAW because it uses two kinds of metal wires (same or dissimilar alloy), when the feeding material is the same. The following is in the order of GMAW, CMT, PAW, and GTAW $^{12)}$. The GMAW-based WAAM is using consumable electrodes and it is coaxial to the heat source, hence easier to plan the tool path with less interference $^{5)}$. Meanwhile, GMAW-based WAAM has rela-

Table 2 Comparison of various WAAM processes depending on the heat source ${ }^{12)}$

\begin{tabular}{|c|c|c|}
\hline $\begin{array}{c}\text { Heat } \\
\text { source }\end{array}$ & $\begin{array}{l}\text { Specific } \\
\text { process }\end{array}$ & Features \\
\hline \multicolumn{2}{|c|}{ GTAW } & $\begin{array}{l}\text { - Non-consumable electrode } \\
\text { - Separate wire feed } \\
\text { - Wire and torch rotation are needed } \\
\text { - Typical deposition rate: } 1-7 \mathrm{~kg} / \mathrm{h}\end{array}$ \\
\hline \multirow{3}{*}{ GMAW } & GMAW & $\begin{array}{l}\text { - Consumable electrode (wire) } \\
\text { - Poor arc stability } \\
\text { - High amount of spatter } \\
\text { - Typical deposition rate: } 3-4 \mathrm{~kg} / \mathrm{h}\end{array}$ \\
\hline & $\begin{array}{l}\text { Cold } \\
\text { metal } \\
\text { transfer } \\
(\mathrm{CMT})\end{array}$ & $\begin{array}{l}\text { - Consumable electrode (wire) } \\
\text { - Low heat input process with less } \\
\text { spatter } \\
\text { - High process tolerance } \\
\text { - Feasible to the AM of non-ferrous } \\
\text { alloys } \\
\text { - Typical deposition rate: } 4-6 \mathrm{~kg} / \mathrm{h}\end{array}$ \\
\hline & $\begin{array}{l}\text { Tandem } \\
\text { GMAW }\end{array}$ & $\begin{array}{l}\text { - Two consumable electrodes (wire) } \\
\text { - Dissimilar composition wire can be } \\
\text { used readily to make AM product } \\
\text { composed with intermetallic material } \\
\text { - Typical deposition rate: } 6-8 \mathrm{~kg} / \mathrm{h}\end{array}$ \\
\hline \multicolumn{2}{|c|}{ PAW } & $\begin{array}{l}\text { - Non-consumable electrode } \\
\text { - Separate wire feed } \\
\text { - Wire and torch rotation are needed } \\
\text { - Typical deposition rate: } 2-6 \mathrm{~kg} / \mathrm{h}\end{array}$ \\
\hline
\end{tabular}

tively limited volume and size of product due to its large melt pool and high heat input. The CMT-based WAAM is one of the alternative processes that can reduce the melt pool size with less heat input through the wire push-pull control ${ }^{4,5,8,9)}$. The CMT-based WAAM is feasible to fabricating most ferrous and non-ferrous materials, but known as not to $\mathrm{Ti}$ alloy because the arc wanders during the process and surface roughness would be increased $^{5,6)}$. GTAW- and PAW-based WAAM has relatively high AM product quality and feasible to fabricating $\mathrm{Ti}$ alloy especially. However, these have limitations from a view of productivity in relatively low deposition rate, as well as the electrode maintenance, require rotation of the torch and wire, and external wire feeding issue ${ }^{4,5)}$.

Recently, WAAM is getting attention from the metal parts manufacturing industries in worldwide owing to its advantages. As aforementioned, most of the commercial metal wires for conventional arc welding can be utilized for the WAAM ${ }^{4,8,12}$. And most of the arc welding facilities already using broadly also can be adapted for $\mathrm{WAAM}^{4,6,8)}$. Therefore, it can be said that the WAAM can save huge upfront capital costs rather than the powder-based AM, or the AM using laser heat sources ${ }^{6,8,10)}$. Further, compared to the powder-based AM, WAAM has no limitation in dimension or volume of product because it does not require any chamber, and hence the building capacity of WAAM is possibly expanded to the meter scale sizes ${ }^{4-6,8}$. And the material efficiency is almost $100 \%$, so that there is absence of needs for the recycling process of material as does in powder-based $\mathrm{AM}^{4-6)}$. Besides, it can save fabrication time and post-machining time by 40-60\% and 15-20\% rather than the traditional subtractive manufacturing processes, respectively ${ }^{11,12)}$. Due to these advantages, WAAM is being a competitive and promising process for decades. To date, research and development of the WAAM processes and optimization of it using ferrous and non-ferrous metals are actively being in all regions and all sections; from a traditional fabricating industry 
to automobile, marine, architecture, nuclear energy, bio, as well as the aerospace industries ${ }^{4,8}$.

\section{WAAM of non-ferrous metals}

The parts for the automobile, marine, aviation, and aerospace industries have being need lighter parts more and more, following the trends of the eco-friendly. And the traditional parts making industries such as casting is being suppressed by the trend of carbon trading due to the certificated emissions reduction (CER). Recently, as induced by the stricter global environmental regulations, AM processes and non-ferrous alloy parts attract high attention from the kinds of industries. Meanwhile, Al and $\mathrm{Mg}$ alloys are the reflective metal alloys and have poor laser coupling efficiency ${ }^{6}$. Also, it is prone to form a high fraction of porosity due to its high reactivity when the powder metal is used for $\mathrm{AM}$ of $\mathrm{Al}$ and $\mathrm{Mg}$ alloys ${ }^{13,14)}$. Fortunately, the WAAM is the alternative process which is independent with coupling efficiency, instead, has almost $100 \%$ of material and energy efficiency. Thus, the WAAM of $\mathrm{Al}$ and $\mathrm{Mg}$ alloys is a promising sector and possibly rising its usage in high value-added components such as aerospace, aviation, marine, biomedical, etc. within a decade. In this paper, it is discussed about the current progress on the non-ferrous WAAM technics and arise issues especially $\mathrm{Al}$ and $\mathrm{Mg}$ alloys.

\subsection{WAAM of aluminum alloys}

Al alloys are broadly used in automobile, aerospace, aviation, marine, rail industries due to their low density and high corrosion resistance. Recently, the application of the Al alloys in the industry is moving from plate and beam type to structural parts and complex shape components as the AM technologies are improved. A key Al alloys are the $2 \mathrm{xxx}, 4 \mathrm{xxx}, 5 \mathrm{xxx}$, and $7 \mathrm{xxx}$ series $^{15)}$. Arc welding of Al alloys is studied a lot for dozens of years and the techniques and know-how are somewhat established firmly. Therefore, the study of the WAMM of Al alloys are being done actively and it is relatively reported a lot. There are numerous studies are already reported regarding the WAAM of Al alloys, and some of it listed in Table 3. The chemical compositions of the Filler metals mentioned in Table 3 are listed in Table 4. There are the studies using $2 \mathrm{xxx}$, 4xxx, and $5 \mathrm{xxx}$ series filler metal, yet using the $7 \mathrm{xxx}$ series is none. That is because of the high $\mathrm{Zn}$ content in $7 \mathrm{xxx}$ series which prone to evaporated during the process ${ }^{15}$.

Haselhuhn et al. studied the GMAW-based WAAM using various Al alloy filler metals to evaluate the manufacturability and properties of AM parts ${ }^{16)}$. ER 1100, ER 4043, ER 4943, ER 4047, and ER 5356 were used for fabrication and evaluated. Alloying elements affected the freezing ranges in which represents the time to solidify. Commercially pure ER1100 and near-eutectic ER4047 have narrow freezing ranges and observed smallest bead widths (about 5 and $5.5 \mathrm{~mm}$, respectively), while the alloys with $\mathrm{Mg}$ alloying elements such as ER4943 and ER 5356 showed larger bead widths (about $6.5 \mathrm{~mm}$ ). Increase of the freezing range due to

Table 3 Process parameters and dimensions of product from various heat sources and Al filler metals

\begin{tabular}{|c|c|c|c|c|c|c|}
\hline $\begin{array}{l}\text { Filler } \\
\text { metal }\end{array}$ & $\begin{array}{l}\text { Heat } \\
\text { source }\end{array}$ & $\begin{array}{l}\text { Heat input or } \\
\text { input parameters }\end{array}$ & $\begin{array}{l}\text { Dimensions } \\
\text { of the product }\end{array}$ & $\begin{array}{l}\text { Shielding } \\
\text { gas }\end{array}$ & $\begin{array}{l}\text { Interlayer interval or } \\
\text { temperature control }\end{array}$ & Ref \\
\hline $\begin{array}{l}\text { ER1100 } \\
\text { ER4047 } \\
\text { ER4043 } \\
\text { ER4943 } \\
\text { ER5356 }\end{array}$ & GMAW & $\begin{array}{l}\text { Welder power setting } \\
\quad \text { (unitless): } 1 \\
\text { Travel speed: } 10 \mathrm{~mm} / \mathrm{s}\end{array}$ & $\begin{array}{c}105.6 \times 53 \times 4 \times \\
25.4 \mathrm{~mm} \\
(\text { block })\end{array}$ & $\begin{array}{c}\text { Pure Ar } \\
(14.4 \mathrm{~L} / \mathrm{min})\end{array}$ & $\begin{array}{l}\text { Pause } 1 \text { minute } \\
\text { after each layer }\end{array}$ & 16) \\
\hline ER5356 & $\begin{array}{l}\text { DC pulsed } \\
\text { MIG/MAG }\end{array}$ & - & $\begin{array}{c}190 \times 135 \times 45 \mathrm{~mm} \\
(\text { block })\end{array}$ & $\begin{array}{c}\text { Pure Ar } \\
(20 \mathrm{~L} / \mathrm{min})\end{array}$ & $\begin{array}{c}\text { Below } 50 \text { and } \\
100{ }^{\circ} \mathrm{C} \\
\end{array}$ & 17) \\
\hline ER2024 & CMT & Heat input: $118 \mathrm{~J} / \mathrm{mm}$ & $\begin{array}{c}- \\
(\text { wall }) \\
\end{array}$ & - & - & 15) \\
\hline $\begin{array}{l}\text { ER4043 } \\
\text { ER4210 } \\
\text { ER4220 }\end{array}$ & CMT & $\begin{array}{c}\text { Current: } 120-130 \mathrm{~A} \\
\text { Voltage: } 20.4-21.4 \mathrm{~V} \\
\text { Travel speed: } 10 \mathrm{~mm} / \mathrm{s}\end{array}$ & $\begin{array}{c}- \\
\text { (wall) }\end{array}$ & $\begin{array}{l}\text { Pure Ar } \\
(25 \mathrm{~L} / \mathrm{min})\end{array}$ & $\begin{array}{l}\text { Between } \\
160-180{ }^{\circ} \mathrm{C}\end{array}$ & 18) \\
\hline $\mathrm{Al}-5 \mathrm{Mg}$ & CMT & $\begin{array}{c}\text { Current: } 156 \mathrm{~A} \\
\text { Volatege: } 15.2 \mathrm{~V} \\
\text { Travel speed: } 8 \mathrm{~mm} / \mathrm{s} \\
\text { Current: } 115 \mathrm{~A} \\
\text { Volatege: } 18.0 \mathrm{~V} \\
\text { Travel speed: } 6 \mathrm{~mm} / \mathrm{s}\end{array}$ & $\begin{array}{l}200 \mathrm{~mm} \text { long } \\
\text { (wall) }\end{array}$ & - & - & 19) \\
\hline ER2319 & $\begin{array}{l}\text { CMT-ADV } \\
\text { and } \\
\text { CMT-PADV* }^{*}\end{array}$ & 112.2 and $189.1 \mathrm{~J} / \mathrm{mm}$ & $\begin{array}{c}500 \times 200 \mathrm{~mm} \\
\quad(\text { wall })\end{array}$ & $\begin{array}{l}\text { Pure Ar } \\
(25 \mathrm{~L} / \mathrm{min})\end{array}$ & - & 20) \\
\hline
\end{tabular}

* CMT-ADV: CMT-Advanced, CMT-PADV: CMT-Pulse Advanced 
Table 4 Chemical compositions of the filler metals listed in table 3

\begin{tabular}{|c|c|c|c|c|c|c|c|c|c|c|}
\hline Filler metal & $\mathrm{Cu}$ & $\mathrm{Si}$ & $\mathrm{Mn}$ & $\mathrm{Mg}$ & $\mathrm{Fe}$ & $\mathrm{Zn}$ & $\mathrm{Be}$ & $\mathrm{Ti}$ & $\mathrm{Cr}$ & $\mathrm{Al}$ \\
\hline ER1100 & $0.05 \sim 0.2$ & - & 0.05 & - & - & 0.1 & 0.0003 & - & - & Bal. \\
\hline ER4047 & 0.3 & $11 \sim 13$ & 0.15 & 0.1 & 0.8 & 0.2 & - & - & - & Bal. \\
\hline ER4043 & 0.3 & $4.5 \sim 6.0$ & 0.05 & $0.05 \mathrm{max}$ & 0.8 & 0.1 & 0.0003 & 0.2 & - & Bal. \\
\hline ER4943 & 0.1 & $5.0 \sim 6.0$ & 0.05 & $0.1 \sim 0.5$ & 0.4 & 0.1 & 0.0003 & 0.15 & - & Bal. \\
\hline ER5356 & 0.1 & 0.25 & $0.05 \sim 0.2$ & $4.5 \sim 5.5$ & 0.4 & 0.1 & 0.0008 & $0.06 \sim 0.2$ & $0.05 \sim 0.2$ & Bal. \\
\hline ER2024 & $3.8 \sim 4.9$ & 0.5 & $0.3 \sim 0.9$ & $1.2 \sim 1.8$ & 0.5 & 0.25 & - & 0.15 & 0.1 & Bal. \\
\hline ER4043 & 0.3 & $4.5 \sim 6.0$ & 0.05 & 0.05 & 0.08 & 0.1 & 0.003 & 0.2 & - & Bal. \\
\hline
\end{tabular}

the alloying elements such as $\mathrm{Mg}$ decrease the metal fluidity, and it results in more prone to form a shrinkage porosity $^{21,22)}$. The volume fraction of porosity within the deposited metal of ER 1100 showed only $0.6 \%$ while the ER5356 showed about $2 \%$. On the other hand, the addition of $\mathrm{Si}$ alloying element would increase the liquid density and decrease the solid density, due to Si expanding upon the solidification, so that results in less shrinkage porosity ${ }^{23)}$. As a result, the AM block made of ER 5356 showed the highest porosity within it and largest difference in performance rather forgings in a bad way. While the 4xxx series showed less fraction of porosities within the block, as shown in Fig. 3. Li et al. also reported that the effect of the $\mathrm{Mg}$ alloying element in WAAM of 4xxx series Al alloy filler metals, and concluded that the increase in $\mathrm{Mg}$ alloying content results in the tendency of prone to form a porosity within WAAM product ${ }^{18)}$.

Porosity within the AM product would induce the micro-cracks on the periphery and act as a weak point, and hence degrade the mechanical properties such as strength, elongation, fatigue, etc. ${ }^{24,25)}$. The formation of

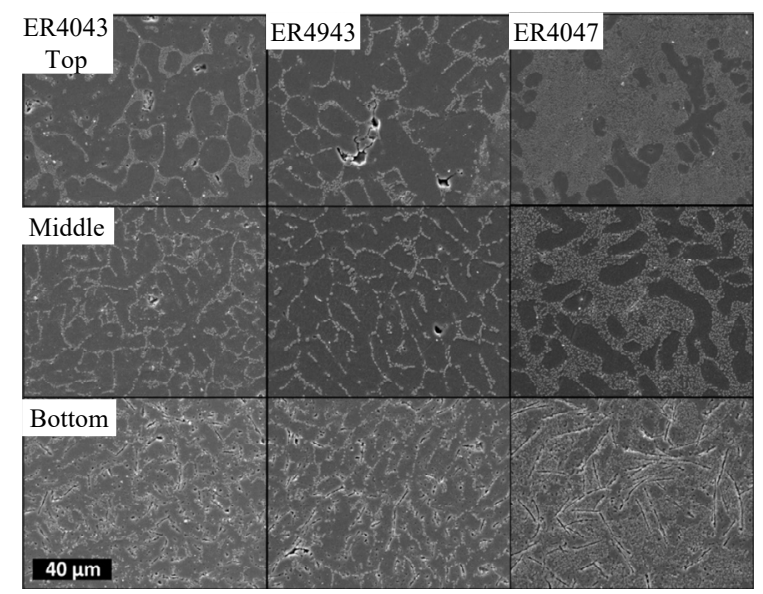

Fig. 3 Scanning electron images of $4 \mathrm{xxx}$ series test specimens. The images were taken from the bottom, top, and middle of the printed block ${ }^{16)}$ porosity is influenced by various factors. The first factor is the alloying elements such as $\mathrm{Mg}$ and $\mathrm{Si}$ as discussed above. Also, the alloying of $\mathrm{Cu}$ elements in $\mathrm{Al}$ alloy such as $\mathrm{Cu}$-rich ER2319 increases the hydrogen solubility in liquid $\mathrm{Al}$ alloy and causes an increase in the formation of porosity during solidification ${ }^{22,26,27)}$. The second factor is the excessive heat input during the WAAM. High heat input is directly connected with the high current, voltage, and wire feed rate which is in proportion to the deposition rate. It is obvious that the deposition rate is good as large as possible. However, the excessive heat input results in the coarsening of microstructure and less grain boundaries ${ }^{26}$. This can be promote liquation along the grain boundaries and entrapment of the gas, so that increase the formation of the porosity ${ }^{28,29)}$. The third factor is contamination. The wire and/or substrate oxidation greatly affect the high oxygen concentration in the melt pool and liquid $\mathrm{Al}$ and results in the formation of porosity ${ }^{30)}$.

The formation of porosity can be suppressed in various ways. The first is using CMT-based WAAM processes such as CMT, CMT-Pulse (CMT-P), CMT-ADV, and CMT-PADV ${ }^{15,18-20,22,32)}$. CMT-based technics are the process that uses push-pull technics on the wire feeding and controls the heat input relatively low level, and hence it is feasible to the WAAM of low melting temperature metals such as $\mathrm{Al}$ and $\mathrm{Mg}$ alloys ${ }^{32}$. Cong et al. reported that the effect of each CMT-based technics on the porosity formation within deposition of ER2219 as shown in Fig. $4^{31)}$. As per their report, CMT has deep penetration and thus has the longest path to hydrogen escape from the melt pool. As a result, it was observed micro-sized porosities $(10-100 \mathrm{~mm})$ in the upper and lower regions of the cross-section. On the other hand, CMT-P, CMT-ADV, and CMT-PADV showed less amount of porosity and smaller sized, but CMT-PADV was somewhat cold-welded and hence not appropriate for the WAAM due to its less wet angle. Gu et al. also compared the differences in porosity of the WAAM 


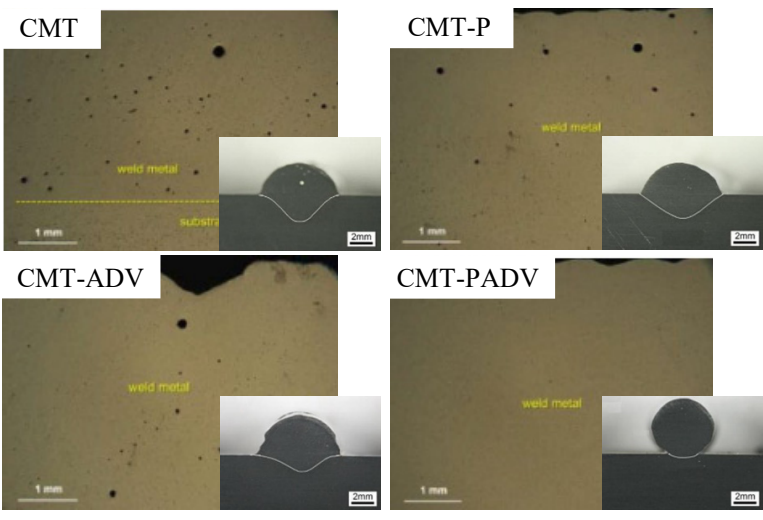

Fig. 4 Variation of porosity formation depending on the different process modes ${ }^{31)}$

product using CMT-P and CMT-PADV ${ }^{20)}$.

Another approach to decrease the porosity in WAAM of Al alloy is the control the temperature in between each layer adapting dwell time. Derekar et al. reported that the difference in the volume of porosity depending on the different interlayer temperatures given as 50 and $100{ }^{\circ} \mathrm{C}^{17)}$. The substrate was heated up the first layer to meet the interlayer temperature from the beginning of the experiment. And then, from the second layer during interval time was given till the product cooled down and meet the interlayer temperature during fabrication of the about 45 layers of each. The higher interlayer temperature condition $\left(100{ }^{\circ} \mathrm{C}\right)$ showed about $10 \%$ less volume fraction of porosity and the size of the porosity was smaller than lower interlayer temperature condition $\left(50{ }^{\circ} \mathrm{C}\right)$. Despite the grain size difference in the two conditions as shown in Fig. 5, the higher interlayer temperature condition $\left(100{ }^{\circ} \mathrm{C}\right)$ showed slightly higher tensile strength and higher elongations due to the less volume fraction of porosity. Meanwhile, Fixter et al. utilized interpass rolling as well as the solution heat- $t$ reatment (ST) to eliminate the porosity the WAAM product made of ER2024 ${ }^{15}$. It was found that the interpass rolling has significantly reduce the amount of porosity in WAAM product by the pore closure as well as the increase the rate of hydrogen dislocation pipe diffusion to free surfaces during subsequent ST, as shown in Fig. 6. And it was suggested by the Hauser et al. to
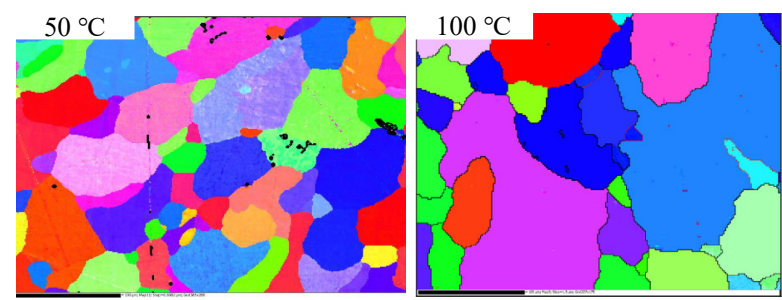

Fig. 5 Invers pole figure map of WAAM product made of ER5356. The black regions represent internal voids ${ }^{17)}$

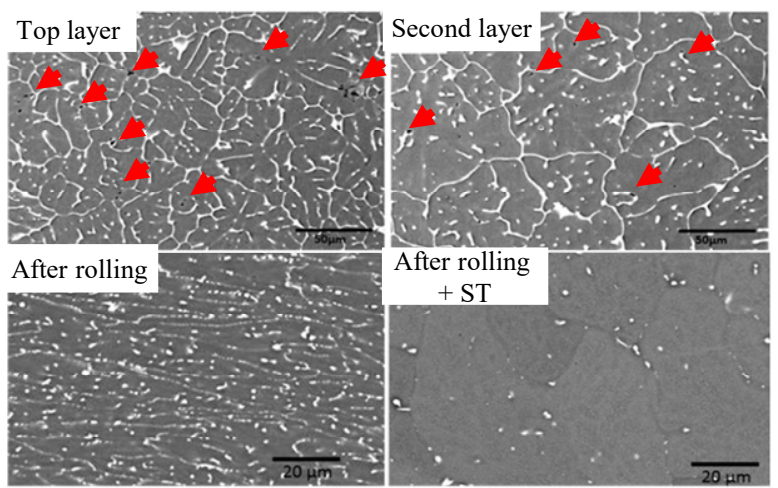

Fig. 6 Porosity observed in the WAAM product by SEM. The red arrows represent the locations of porosity ${ }^{15}$ )

reduce the oxygen concentration on weld through the control of contact tip to work distance (CTWD) in which the distance from the end of the contact tip to the work piece ${ }^{33)}$.

The presence of hot cracking and distortion is another challenging task on WAAM of Al alloys. Hot cracking is mainly due to the wide freezing range of $\mathrm{Al}$ alloys such as $5 \mathrm{xxx}$ series as discussed with afore ${ }^{21,22,34)}$. Fixter et al. established an equation for hot cracking susceptibility (HSC) prediction and matched with their own actual WAAM product made of ER2024 ${ }^{15}$. Meanwhile, the distortion is mainly due to the huge thermal gradients within the WAAM product including the substrate during $\mathrm{WAAM}^{16,26)}$. The key to reduce or eliminate distortion of WAAM product is prevent huge thermal gradients during and after WAAM. The combination of interval time between each pass or layer ${ }^{15,17,19)}$ and preheating of the substrate ${ }^{32)}$ can lower the thermal gradients, in which directly connected with thermal repetitive contraction and expansion.

\subsection{WAAM of Mg alloys}

$\mathrm{Mg}$ alloys are the lightest structural metal alloy and has good material properties such as high specific strength, good damping, electromagnetic shielding, machining, recyclability, biodegradability, etc ${ }^{11,14,35-37)}$. For this reason, many studies and trials are being conducted in industries of automobile, railway, aviation, aerospace, military, and biomedical ${ }^{11,36,37)}$. Most of the parts made of $\mathrm{Mg}$ alloys are manufactured by traditional parts making processes such as machining, gravity casting or die-casting ${ }^{14,35-38)}$. However, recently, the demand on the lightweight monolithic part with large, medium scales and complex design is increased as the arising of the AM processes ${ }^{11,14,37)}$. WAAM of Mg alloy can be a alternative fabrication method to meet those needs in industries. But, unfortunately, $\mathrm{Mg}$ alloys are relatively difficult to $\mathrm{AM}$ due to its nature of high reactivity ${ }^{14)}$. It 
Review on the Wire Arc Additive Manufacturing Process and Trends in Non-ferrous Alloys

Table 5 Process parameters and dimensions of product from various heat sources and $\mathrm{Mg}$ filler metals

\begin{tabular}{|c|c|c|c|c|c|c|}
\hline $\begin{array}{l}\text { Filler } \\
\text { metal }\end{array}$ & $\begin{array}{c}\text { Heat } \\
\text { source }\end{array}$ & $\begin{array}{l}\text { Heat input or } \\
\text { input parameters }\end{array}$ & $\begin{array}{l}\text { Dimensions of the } \\
\text { product }\end{array}$ & Shielding gas & $\begin{array}{l}\text { Interlayer interval or } \\
\text { temperature control }\end{array}$ & Ref \\
\hline AZ31B & GMAW & $\begin{array}{c}\text { Current: } 100 \mathrm{~A} \\
\text { Volatege: } 10 \mathrm{~V} \\
\text { Travel speed: } 400-800 \mathrm{~mm} / \mathrm{min}\end{array}$ & $\begin{aligned} & 40 \times 60 \times 35 \mathrm{~mm} \\
&(\text { block }) \\
& 140 \times 25 \times 35 \mathrm{~mm} \\
& \\
&(\text { block })\end{aligned}$ & $\begin{array}{l}\text { Pure Ar } \\
(25 \mathrm{~L} / \mathrm{min})\end{array}$ & $\begin{array}{c}\text { Time interval: } 20 \\
\text { seconds }\end{array}$ & 38) \\
\hline AZ31 & $\begin{array}{l}\text { CMT and } \\
\text { CMT-P }\end{array}$ & $\begin{array}{c}\text { Current: } 125-350 \mathrm{~A} \\
\text { Voltage: - } \\
\text { Travel speed: } 600 \mathrm{~mm} / \mathrm{min}\end{array}$ & $\begin{array}{l}250 \times 150 \\
\quad(\text { wall })\end{array}$ & $\begin{array}{l}\text { Pure Ar } \\
(18 \mathrm{~L} / \mathrm{min})\end{array}$ & $\begin{array}{c}\text { Time interval: } 180 \\
\text { seconds }\end{array}$ & 11) \\
\hline AZ31 & GTAW & $\begin{array}{l}\text { Current: } 65 \mathrm{~A} \\
\text { Pulse frequency: } 1-500 \mathrm{~Hz} \\
\text { Travel speed: } 600 \mathrm{~mm} / \mathrm{min}\end{array}$ & $\begin{array}{l}100 \times 10 \mathrm{~mm} \\
\quad(\text { wall })\end{array}$ & $\begin{array}{l}\text { Pure Ar } \\
(20 \mathrm{~L} / \mathrm{min})\end{array}$ & - & 39) \\
\hline AZ80M & GTAW & $\begin{array}{c}\text { Current: } 75 \mathrm{~A} \\
\text { Pulse frequency: } 8 \mathrm{~Hz} \\
\text { Travel speed: } 300 \mathrm{~mm} / \mathrm{min}\end{array}$ & $\begin{array}{c}- \\
\text { (wall) }\end{array}$ & $\begin{array}{l}\text { Pure Ar } \\
(20 \mathrm{~L} / \mathrm{min})\end{array}$ & $\begin{array}{c}\text { Time interval: } 160 \\
\text { seconds }\end{array}$ & 37) \\
\hline
\end{tabular}

is prone to oxidizes uncontrollably in atmospheric environment, and thus easy to form a high level of porosity in $\mathrm{AM}$ parts ${ }^{14)}$. Further, it is a kind of heat-sensitive material so that the coarsening of microstructure, hot cracking, distortion can easily occur ${ }^{11,14)}$. Also, the commercial availability of the $\mathrm{Mg}$ alloy wires is low till now, and hence the researches on the WAAM of Mg alloys are barely done and reported, until now ${ }^{35,37,39)}$. Some of the researches on the WAAM of Mg alloys are listed in the Table 5.

Most of the studies reported till now are dealt with basic research on the WAAM of Mg alloys such as optimization of parameters, trials of the WAAM with selected parameter, and microstructural and mechanical evaluation $^{11,14,35,37-39)}$. The trial results of the WAAM product made of $\mathrm{Mg}$ alloys are shown in Fig. 7. The wall structure products are somewhat able to fabricate with less defects and distortion, while the 3-dimensional blocks are still need more optimization. It can be observed the side collapse (Fig. 7a and 7c) and rough surfaces on both the top and side (Fig. 7). Wang et al. ${ }^{11)}$ investigated the microstructural feature of the thin wall made of AZ31 alloy using the WAAM process which is shown in Fig. 7b. The micro pores were found in a HAZ (a)
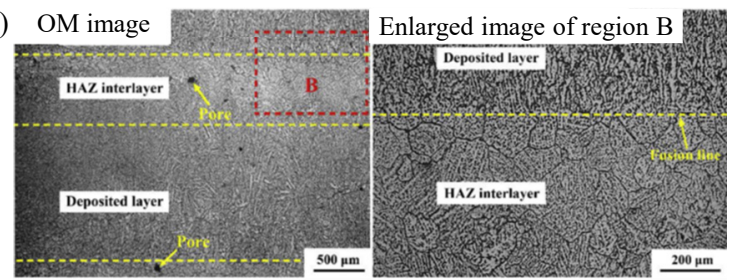

(b) Layer boundary
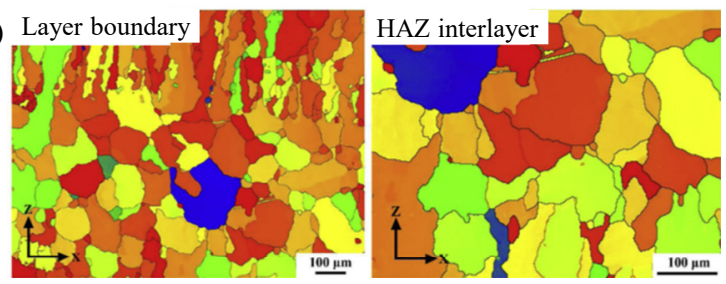

Fig. 8 (a) Optical microscope images and (b) invers pole figure maps of WAAM product made of AZ31 Mg alloy $^{11)}$

interlayer as shown in Fig. 8a. The HAZ interlayer was composed of coarser grains with serrated grain boundaries with about $50 \%$ of high angle grain boundaries (HAGBs), while the deposited layer was rated only about $32 \%$ of HAGBs as shown in Fig. 8 b.

The field of WAAM of Mg alloys is just got started to study compared to steel or Al alloys, and still most of the
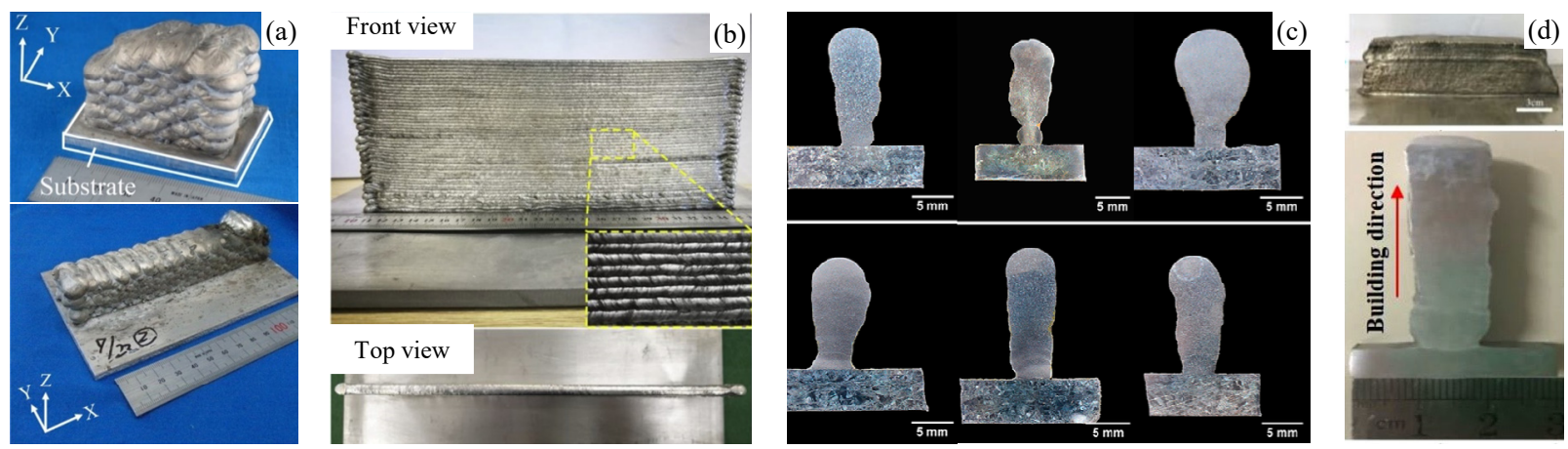

Fig. 7 Images of the WAAM product made by (a) Takagi et al. ${ }^{38)}$, (b) Wang et al. ${ }^{11)}$, (c) Guo et al. ${ }^{39)}$, and (d) Guo et al. ${ }^{37)}$ 
areas are not uncovered or discovered yet. Therefore, it could be a blue ocean to the researchers who are working with welding technology and material science as long as unless the demands are decreased due to discover or develop new material who can replace $\mathrm{Mg}$ and its alloys.

\section{Closing remarks and future prospects}

In this review paper, it is discussed that what is the $\mathrm{AM}$ and WAAM as well as the status and trends in WAAM of non-ferrous materials especially $\mathrm{Al}$ and $\mathrm{Mg}$. As aforementioned, the needs and demands of the AM and WAAM of Al and Mg alloys would be increased as per the global trends in automation with the fourth industrial revolution and in eco-friendly policies due to the CER. Compared to the conventional fabricating methods, WAAM of $\mathrm{Al}$ and $\mathrm{Mg}$ alloys has very short history and there are still lots of things to be studied and optimized with. In here, it was focused on the process variations and methodologies, while the WAAM (as well as other AM processes) needs the cooperation with not only welding and mechanical engineering but also the metallurgy, thermodynamics, finite element analysis, aerodynamics, hydrodynamics, etc. to meet the needs of potential customers in kinds of industries. Further, the specialized equipment or system also should be considered to ensure the material handling safety and the quality of WAAM product due to its high risk of reacting with atmospheric oxygen.

\section{Acknowledgement}

This research was conducted with the support of the Ministry of Economy and Finance (MOEF) for studies on "F/APRON\&MBR+Bolt $\mathrm{CO}_{2}$ welding process realtime monitoring technology development (JH210016)." and "Development of Smart Manufacturing Technology for Low Temperature Fuel Tank for LNG Ships (JA210008)."

ORCID: Jae-Deuk Kim: https://orcid.org/0000-0002-9390-8696 ORCID: Changwook Ji: https://orcid.org/0000-0002-5158-5243

\section{Reference}

1. ISO/ASTM 52900:2015(en), Additive manufacturing General principles - Terminology, International Standardization Organization (ISO) (2015).

2. W. E. Frazier, Metal additive manufacturing: A review, J. Mater. Eng. Perform. 23(6) (2014) 1917-1928. https://doi.org/10.1007/s11665-014-0958-z

3. P. Kazanas, P. Deherkar, P. Almeida, H. Lockett, and S
Williams. Fabrication of geometrical features using wire and arc additive manufacture, Proc. Inst. Mech. Eng.

Part B J. Eng. Manuf. 226(6) (2012) 1042-51.

https://doi.org/10.1177/0954405412437126

4. W. Jin, C. Zhang, S. Jin, Y. Tian, D. Wellmann, and W. Liu, Wire arc additive manufacturing of stainless steels: A review, Appl. Sci. 10(5) (2020) 1563-1582. https://doi.org/10.3390/app10051563

5. S. W. Williams, F. Martina, A. C. Addison, J. Ding, G. Pardal, and P. Colegrove, Wire + Arc additive manufacturing, Mater. Sci. Technol. 32(7) (2016) 641-647. https://doi.org/10.1179/1743284715Y.0000000073

6. C. R. Cunningham, J. M. Flynn, A. Shokrani, V. Dhokia, and S. T. Newman, Invited review article: Strategies and processes for high quality wire arc additive manufacturing, Addit. Manuf. 22 (2018) 672-686.

https://doi.org/10.1016/j.addma.2018.06.020

7. J. J. Lewandowski and M. Seifi, Metal Additive Manufacturing: A Review of Mechanical Properties, Annu. Rev. Mater. Res. 46 (2016) 151-186.

https://doi.org/10.1146/annurev-matsci-070115-032024

8. J. W. Kim, J. D. Kim, J. Y. Cheon, and C. W. Ji, Effect of filler metal type on microstructure and mechanical properties of fabricated nial bronze alloy using wire arc additive manufacturing system, Metals. 11(3) (2021) 1-11. https://doi.org/10.3390/met11030513

9. J. D. Kim, J. W. Kim, J. Y. Cheon, Y.D. Kim, and C.W. $\mathrm{Ji}$, Effect of shielding gases on the wire arc additive manufacturability of $5 \mathrm{Cr}-4$ Mo tool steel for die casting mold making, J. Korean Inst. Met. Mater. 58(12) (2020) 852-862.

https://doi.org/10.3365/KJMM.2020.58.12.852.

10. E. A. Bonifaz and J. S. Palomeque, A mechanical model in wire + Arc additive manufacturing process, Prog. Addit. Manuf. 5(2) (2020) 163-169. https://doi.org/10.1007/s40964-020-00112-y

11. P. Wang, H. Zhang, H. Zhu, Q. Li, and M. Feng, Wirearc additive manufacturing of AZ31 magnesium alloy fabricated by cold metal transfer heat source: Processing, microstructure, and mechanical behavior, J. Mater. Process. Technol. 288 (2021) 116895. https://doi.org/10.1016/j.jmatprotec.2020.116895

12. B. Wu, Z. Pan, D. Ding, D. Cuiuri, H. Li, J. Xu, and J. Norrish, A review of the wire arc additive manufacturing of metals: properties, defects and quality improvement, J. Manuf. Process. 35 (2018) 127-139. https://doi.org/10.1016/j.jmapro.2018.08.001

13. N. T. Aboulkhair, M. Simonelli, L. Parry, I. Ashcroft, C. Tuck, and R. Hague, 3D printing of Aluminium alloys: Additive Manufacturing of Aluminium alloys using selective laser melting, Prog. Mater. Sci. 106 (2019) 100578 . https://doi.org/10.1016/j.pmatsci.2019.100578

14. R. Karunakaran, S. Ortgies, A. Tamayol, F. Bobaru, and M.P. Sealy, Additive manufacturing of magnesium al- 
loys, Bioact. Mater. 5(1) (2020) 44-54.

https://doi.org/10.1016/j.bioactmat.2019.12.004

15. J. Fixter, J. Gu, J. Ding, S.W. Williams, and P.B. Prangnell, Preliminary investigation into the suitability of $2 \mathrm{xxx}$ alloys for Wire-Arc Additive Manufacturing, Mater. Sci. Forum. 877 (2017) 611-616.

https://doi.org/10.4028/www.scientific.net/MSF.877.611

16. A. S. Haselhuhn, M. W. Buhr, B. Wijnen, P. G. Sanders, and J. M. Pearce, Structure-property relationships of common aluminum weld alloys utilized as feedstock for GMAW-based 3-D metal printing, Mater. Sci. Eng. A 673 (2016) 511-523.

https://doi.org/10.1016/j.msea.2016.07.099

17. K. Derekar, J. Lawrence, G. Melton, A. Addison, X. Zhang, and $\mathrm{L}$. Xu, Influence of Interpass Temperature on Wire Arc Additive Manufacturing (WAAM) of Aluminium Alloy Components, MATEC Web Conf. 269 (2019) 05001. https://doi.org/10.1051/matecconf/201926905001

18. C. Li, H. Gu, W. Wang, S.Wang, L. Ren, Z. Wang, Z. Ming, and Y. Zhai, Effects of magnesium on the microstructure and properties of Al-Si alloy deposited by wire and arc-based additive manufacturing, Mater. Technol. 36(13) (2021) 793-798.

https://doi.org/10.1080/10667857.2020.1797284

19. K. Oyama, S. Diplas, M. M'hamdi, A. E. Gunnæs, and A. S. Azar, Heat source management in wire-arc additive manufacturing process for $\mathrm{Al}-\mathrm{Mg}$ and $\mathrm{Al}-\mathrm{Si}$ alloys, Addit. Manuf. 26 (2019) 180-192. https://doi.org/10.1016/j.addma.2019.01.007

20. J. Gu, B. Cong, J. Ding, S.W. Williams, and Y. Zhai, WIRE+ARC additive manufacturing of aluminium, 25th Annu Int Solid Free Fabr Symp - An Addit. Manuf. Conf. SFF 2014, Texas, USA (2014) 451-458.

21. J. E. Hatch, Aluminum: Properties and Physical Metallurgy, American Society for Metals, Metals Park, Ohio, (1984) 424.

22. K.S. Derekar, A review of wire arc additive manufacturing and advances in wire arc additive manufacturing of aluminium, Mater. Sci. Technol. 34(8) (2018) 895-916. https://doi.org/10.1080/02670836.2018.1455012

23. T. Magnusson, L. Arnberg, Density and solidification shrinkage of hypoeutectic aluminum-silicon alloys, Metall. Mater. Trans. A 32(10) (2001) 2605-2613. https://doi.org/10.1007/s11661-001-0050-9

24. H. Mayer, M. Papakyriacou, B. Zettl, and S.E. StanzlTschegg, Influence of porosity on the fatigue limit of die cast magnesium and aluminium alloys, Int. J. Fatigue. 25(3) (2003) 245-256. https://doi.org/10.1016/S0142-1123(02)00054-3

25. H. Su, S. Bhuiyan, H. Toda, K. Uesugi, A. Takeuchi, and Y. Watanabe, Influence of intermetallic particles on the initiation and growth behavior of hydrogen micropores during high-temperature exposure in $\mathrm{Al}-\mathrm{Zn}-\mathrm{Mg}-\mathrm{Cu}$ aluminum alloys, Scr. Mater. 135 (2017) 19-23.

https://doi.org/10.1016/j.scriptamat.2017.03.020

26. S. Thapliyal, Challenges associated with the wire arc additive manufacturing (WAAM) of aluminum alloys, Mater. Res. Express. 6(11) (2019) 112006. https://doi.org/10.1088/2053-1591/ab4dd4

27. S. G. Shabestari and H. Moemeni, Effect of copper and solidification conditions on the microstructure and mechanical properties of Al-Si-Mg alloys, J. Mater. Process. Technol. 153-154(1-3) (2004) 193-198. https://doi.org/10.1016/j.jmatprotec.2004.04.302

28. B. Cong, J. Ding, and S. Williams, Effect of arc mode in cold metal transfer process on porosity of additively manufactured $\mathrm{Al}-6.3 \% \mathrm{Cu}$ alloy, Int. J. Adv. Manuf. Technol. 76(9-12) (2015) 1593-1606.

https://doi.org/10.1007/s00170-014-6346-x

29. Y. Sharir, J. Pelleg, and A. Grill, Effect of arc vibration and current pulses on microstructure and mechanical properties of TIG tantalum welds, Met. Technol. 5(1) (1978) 190-196.

https://doi.org/10.1179/mt.1978.5.1.190

30. J. L. Gu, J. L. Ding, B. Q. Cong, J. Bai, H. M. Gu, S. W. Williams, and Y.C. Zhai, The Influence of Wire Properties on the Quality and Performance of Wire+ Arc Additive Manufactured Aluminium Parts, $A d v$. Mater. Res. 1081 (2014) 210-214.

https://doi.org/10.4028/www.scientific.net/amr.1081.210

31. B. Cong, R. Ouyang, B. Qi, and J. Ding, Influence of cold metal transfer process and its heat input on weld bead geometry and porosity of aluminum-copper alloy welds, Rare. Met. Mater. Eng. 45(3) (2016) 606-611. https://doi.org/10.1016/s1875-5372(16)30080-7

32. Z. Wang, and Y. Zhang, A review of aluminum alloy fabricated by different processes of wire arc additive manufacturing, J. Mater. Sci. 27(1) (2021) 18-26. https://doi.org/10.5755/j02.ms.22772

33. T. Hauser, R. T. Reisch, P. P. Breese, Y. Nalam, K. S. Joshi, K. Bela, T. Kamps, J. Volpp, and A. F. H. Kaplan, Oxidation in wire arc additive manufacturing of aluminium alloys, Addit. Manuf. 41 (2021). https://doi.org/10.1016/j.addma.2021.101958

34. C. E. Cross, On the origin of weld solidification cracking, Hot Crack Phenom Welds, (2005) 3-18. https://doi.org/10.1007/3-540-27460-X_1

35. S. Gneiger, J. A. Österreicher, A. R. Arnoldt, A. Birgmann, and M. Fehlbier, Development of a high strength magnesium alloy for wire arc additive manufacturing, Metals. 10(6) (2020) 1-14. https://doi.org/10.3390/met10060778

36. J. Tan, and S. Ramakrishna, Applications of magnesium and its alloys: A review, Appl. Sci. 11(15) (2021). https://doi.org/10.3390/app11156861

37. Y. Guo, G. Quan, Y. Jiang, L. Ren, L. Fan, and H. Pan, Formability, microstructure evolution and mechanical properties of wire arc additively manufactured AZ80M 
magnesium alloy using gas tungsten arc welding, $J$. Magnes. Alloy, 9(1) (2021) 192-201. https://doi.org/10.1016/j.jma.2020.01.003

38. H. Takagi, H. Sasahara, T. Abe, H. Sannomiya, S. Nishiyama, S. Ohta, and K. Nakamura, Material-property evaluation of magnesium alloys fabricated using wireand-arc-based additive manufacturing, Addit. Manuf.
24 (2018) 498-507.

https://doi.org/10.1016/j.addma.2018.10.026

39. J. Guo, Y. Zhou, C. Liu, Q. Wu, X. Chen, and J. Lu, Wire arc additive manufacturing of AZ31 magnesium alloy: Grain refinement by adjusting pulse frequency, Materials. (Basel) 9(10) (2016).

https://doi.org/10.3390/ma9100823 